\title{
Synthesis and Antimicrobial Activity of New Pyridine Containing Substituted Phenyl Azetidine-2-One Derivatives
}

\author{
V. Esther Rani*, P. Raveendra Reddy \\ Department of Chemistry, Sri Krishnadevaraya University, Anantapur, Andhra Pradesh, India \\ Email: *vesther9@gmail.com
}

How to cite this paper: Rani, V.E. and Reddy, P.R. (2018) Synthesis and Antimicrobial Activity of New Pyridine Containing Substituted Phenyl Azetidine-2-One Derivatives. Open Journal of Medicinal Chemistry, 8, 22-29.

https://doi.org/10.4236/ojmc.2018.82003

Received: November 23, 2017

Accepted: June 22, 2018

Published: June 25, 2018

Copyright $\odot 2018$ by authors and Scientific Research Publishing Inc. This work is licensed under the Creative Commons Attribution International License (CC BY 4.0).

http://creativecommons.org/licenses/by/4.0/

\begin{abstract}
The most important nitrogen containing heterocycles of pyridine containing substituted phenyl azetidine-2-ones have found pharmacological application such as antibiotics and these compounds also have practical importance. The structure of the new derivatives was confirmed by the spectral data and elemental analyses. Out of five new derivatives, three were revealed mild to moderate activity compared with Streptomycin \& Fluconazole as a reference standard. Among this new series, 3-chloro-1-(4-fluoro phenyl)/(4-chloro phenyl)-4-(pyridine-3-yl) azetidine-2-one ( $4 \mathrm{a} \& \mathrm{~b}$ ) were found most activity.
\end{abstract}

\section{Keywords}

Antibacterial, Antifungal, Azetidin-2-One, Pyridine

\section{Introduction}

Recently, our group newly synthesized derivatives of (4-substituted phenyl)-4-(pyridine-3-yl) azetidin-2-one (4a-e) which showed inhibitory activity against antibacterial and anti fungal. The several studies have been made to investigate the structure activity relation (SAR) of these synthesized derivatives of (4-substituted phenyl)-4-(pyridin-3-yl) azetidin-2-one (4a-e) showing several different activities.

Due to our experience of working with para position for generating antibacterial, and the role of para position in the " $\mathrm{C}$ " ring moiety of phenyl derivatives, we synthesized 10 compounds presenting substituents with different electronic properties ( $\mathrm{F}, \mathrm{Cl}, \mathrm{Br}, \mathrm{CF}_{3}, \mathrm{OCH}_{3}$ ).

Heterocyclic compounds include many of the biochemical materials essential to life. Many naturally occurring antibiotics are heterocyclic compounds. Mod- 
ern society is dependent on synthetic heterocycles for us as drugs.

The newly synthesized derivatives of pyridine contain azetidine-2-one to identify the pyridine system as a group for the development of new antimicrobial agents such as pharmaceutically important pyridine derivatives including the tuberculostat, anti-AIDS, vasodilator used for treating urinary tract, analgesic, anti-inflammatory and an anesthetic [1]-[8].

Heterocycles possessing azetidin-2-one ring were found to show various types of biological activities such as anti-bacterial, anti-fungal [9] [10] [11], anti-convulsing [12] and antimicrobial [13] [14] [15].

\section{Experimental}

\subsection{Materials and Methods}

All the chemicals used in the present investigation were purchased from Sigma-Aldrich chemical company, Inc.USA. And used without further purification.

\subsection{Instruments}

Thin Layer Chromatography was performed on aluminium sheet of silica gel 60F254, E-Merk, Germany using iodine as visualizing agent. Melting points were determined in open capillary tubes on Mel-Temp apparatus and are uncorrected. IR spectra were measured using Nexus, 470-670-760 spectrophotometer FT IR, spectrometer spectrum $8400 \mathrm{~s}$, using $\mathrm{KBr}$ pellets for solid compounds and neat liquid compounds between $\mathrm{KBr}$ plates. NMR spectra were measured at $24^{\circ} \mathrm{C}$ on a Joel $400 \mathrm{MHz}$ spectrometer using deuterium locking ${ }^{13} \mathrm{C}\left({ }^{1} \mathrm{H}\right)$-NMR observation frequency $75 \mathrm{MHz},{ }^{1} \mathrm{H}-\mathrm{NMR}$,observation frequencies, $400 \mathrm{MHz}$.

\section{Microbial Assay (Agar Well Diffusion Method)}

Nutrient agar (Bacto-beef extract $2.5 \mathrm{~g}$; peptone $5 \mathrm{~g}$; sodium chloride $6 \mathrm{~g}$; and distilled water $1000 \mathrm{~mL}$ ) was used for bacteria growth and Asthana and Hawker's (Glucose $6 \mathrm{gr}$; potassium nitrate $4 \mathrm{~g}$; $\mathrm{KH}_{2} \mathrm{PO}_{4} 2.25$ g; hydrated magnesium sulphate $1.25 \mathrm{~g}$ and distilled water $1000 \mathrm{~mL}$ ) media which are used for fungi growth. The media chemicals present study purchased from Merck. The standard bacterial and fungal strains were procured from the Microbial Type Culture Collection (MTCC), Institute of Microbial Technology (IMTECH), and Chandigarh, India. The pure bacterial cultures were maintained on Nutrient Agar Media (NAM) for bacterial and fungal culture on potato dextrose agar (PDA).

These newly synthesized 3-chloro-1-(4-substituted phenyl)-4-(pyridin-3-yl) azetidin-2-one (4a-e) derivatives were performed by antimicrobial activity according to Agar well diffusion method is preferred to be used in this study since it was found to be better than the disc diffusion method suggested by Parekh et al. [16] and also recommended by the National Committee for Clinical Laboratory (NCCLS, 1993). The newly synthesized compounds were used at the con- 
centration of $2 \mathrm{mg} / \mathrm{mL}$ dimethyl sulfoxide as a solvent [17]. A standardized 1 to $2 \times 10^{7} \mathrm{cfu} / \mathrm{mL} 0.5 \mathrm{MC}$ Farland standard was introduced onto the surface of a sterile agar plate and evenly distributed inoculums by using a sterile glass spreader. Simultaneously, $6 \mathrm{~mm}$ wells were cut from the plate using a sterile cork borer. $50 \mu \mathrm{l}$ solution at a concentration of $2.5 \mathrm{mg} / \mathrm{mL}$ of the compounds was introduced into well and incubated at $35^{\circ} \mathrm{C}$ for 24 hours, the inhibition zones were measured with a ruler and compared with the control well containing only 1 $\mathrm{mg} / \mathrm{mL}$ in dimethyl sulfoxide of streptomycin as the standard. The antifungal assay of the compounds was carried out by agar well diffusion method as described by Magaldi et al. [18] $6 \mathrm{~mm}$ diameter open wells punched with a sterile cork borer on cultured plates with test organisms before incubated. The wells were filled with $50 \mu \mathrm{l}$ solution at a concentration of $2.5 \mathrm{mg} / \mathrm{mL}$ of the compounds at $32^{\circ} \mathrm{C}$. After 72 hours, the zones of inhibition were measured and compared with those of the control dimethyl sulfoxide and the standard Fluconazole at a concentration of $1 \mathrm{mg} / \mathrm{mL}$.

\section{Antibacterial assay}

The antibacterial activity of 3-chloro-1-(4-substituted phenyl)-4-(pyridin-3-yl) azetidin-2-one (4a-e) were screened against the Staphylococcus aureus (MTCC-3160) and Bacillus subtilis (MTCC-441) (gram + ve) and Escherichia coli (MTCC-1652) organisms. Here Streptomycin is tested as reference compound to compare the activity.

\section{Antifungal assay}

Antifungal activity of 3-chloro-1-(4-substituted phenyl)-4-(pyridin-3-yl) azetidin-2-one (4a-e) were screened against Pseudomonas aeruginosa (MTCC-467) (gram-ve), Aspergillus niger (MTCC-282) and Penicillium rubrum, our isolate. Here Fluconazole is tested as reference compound to compare the activity. The anti-bcterial and anti-fungal activity of (4a-e) were shown in Table 1.

Table 1. Anti-bcterial and anti-fungal activity 3-chloro-1-(4-substituted phenyl)-4-(pyridin-3-yl) azetidin-2-one (4a-e).

\begin{tabular}{|c|c|c|c|c|c|c|c|c|}
\hline \multirow{3}{*}{ Entry } & \multirow{3}{*}{ COMP } & \multirow{3}{*}{$\mathrm{R}$} & \multicolumn{6}{|c|}{ Zone of inhibition $(\mathrm{mm}) 50 \mu \mathrm{L}$ for well } \\
\hline & & & \multicolumn{3}{|c|}{${ }^{1}$ Anti-bacterial activity } & \multicolumn{3}{|c|}{${ }^{2}$ Anti-fungal activity } \\
\hline & & & S.a & B.s & E.c & P.a & A.n & P.r \\
\hline 1 & $4 \mathrm{a}$ & ${ }^{\star} \mathrm{F}$ & 17 & 18 & 16 & 17 & 16 & 15 \\
\hline 2 & $4 \mathrm{~b}$ & ${ }^{*} \mathrm{Cl}$ & 18 & 17 & 14 & 16 & 14 & 14 \\
\hline 3 & $4 c$ & $\mathrm{Br}$ & 15 & 13 & 10 & 11 & 13 & 12 \\
\hline 4 & $4 \mathrm{~d}$ & $\mathrm{CF}_{3}$ & 12 & 13 & 10 & 07 & 09 & 05 \\
\hline 5 & $4 \mathrm{e}$ & $\mathrm{OCH}_{3}$ & 11 & 07 & 09 & 10 & 04 & 06 \\
\hline Std & \multicolumn{2}{|c|}{ Streptomycin } & 25 & 20 & 20 & 23 & - & - \\
\hline Std & \multicolumn{2}{|c|}{ Fluconazole } & - & - & - & - & 18 & 15 \\
\hline
\end{tabular}

${ }^{1}$ S.a: Staphylococcus aureus, B.s: Bacillus subtilis, E.c: Escherichia coli, P.a: Pseudomonas aeruginosa. ${ }^{2}$ A.n: Aspergillus niger, P.r: Penicillium rubrum. ${ }^{\star}$ Indicates more activity. 


\section{Results and Discussion}

Scheme 1 shows the synthetic route for preparing of (4-substituted phenyl)-4(pyridin-3-yl) azetidin-2-one (4a-e) group by reaction mixture of schiff base (3a-e) with monochloro acetyl chloride. Schif base obtained by condensation of nicotinaldehyde and substituted aniline. The anti-bacterial and anti-fungal activities of (4a-e) were shown in Table 1 . The compounds (4a-e) were tested for antimicrobial activity. Amongst all the tested compounds $4 \mathrm{a} \& 4 \mathrm{~b}$ exhibited higher activity than other which may be due to the presence of electron withdrawing substituents increases the activity when compared with electron donating substituents.

\subsection{General Method for Preparation of Schiff Bases 3(a-e)}

The reaction mixture of nicotinaldehyde (1) $(1.00 \mathrm{mmol})$ and 4-fluoroaniline (2a)/4-chloro/4-bromo/4-(trifluoromethyl)/4-methoxy-aniline (2b-e) (1.00 mmol) were refluxed in ethanol $(20 \mathrm{ml})$ for 1-5 hours. After cooling, the products of Schiff bases (3a-e) were dissolved by adding water and the crude product $3 \mathbf{a}$ or ( $3 \mathrm{~b}-\mathrm{e})$ was precipitated after the reaction mixture was neutralized with potassium carbonate. The precipitate was filtered, washed with water and recrystallised from aqueous EtOH and dried under vacuum over night. 3a: $71 \%$ yield, $\mathrm{mp}$ $161^{\circ} \mathrm{C}, 3 \mathrm{~b}: 70 \%$ yield, $\mathrm{mp} 158^{\circ} \mathrm{C}, 3 \mathrm{c}: 68 \%$ yield, $\mathrm{mp} 160^{\circ} \mathrm{C}, 3 \mathrm{~d}: 74 \%$ yield, $\mathrm{mp}$ $168^{\circ} \mathrm{C}, 3 \mathrm{e}: 70 \%$ yield, $\mathrm{mp} 162^{\circ} \mathrm{C}$.
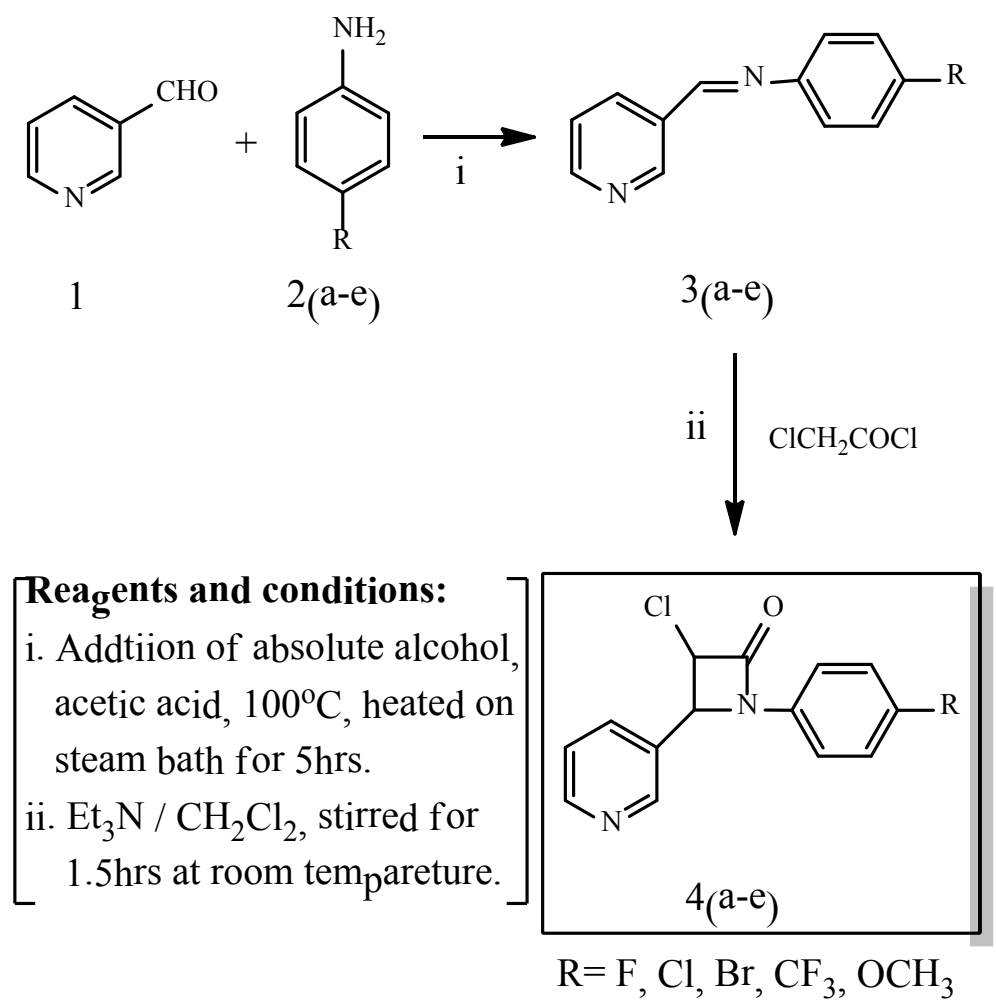

Scheme 1. Synthetic pathway of 3-chloro-1-(4-substituted phenyl)-4-(pyridin-3-yl)azetidin-2-one (4a-e). 


\subsection{General Method for Synthesis of 3-Chloro-1-(4-Substituted Phenyl)-4-(Pyridin-3-Yl) Azetidin-2-One (4a-e)}

The mixture of corresponding Schiff bases $(3 \mathrm{a} / \mathrm{b} / \mathrm{c} / \mathrm{d}$ or $\mathbf{e})(10 \mathrm{mmol})$ with appropriate monochloroacetyl chloride $(10 \mathrm{mmol})$ in presence of triethyl amine $(2$ $\mathrm{mmol})$ in dichloromethane $(20 \mathrm{ml})$ at room temperature. The reaction mixture was boiled under reflux with stirring for 1.5 hours and left at room temperature. At the end of the reaction was neutralized with excess of $\mathrm{NaHCO}_{3}$. The collected precipitate washed with water, dried in vacuum, purified by thin layer chromatography using cyclohexane and ethyl acetate (9:1) solvent mixture as a mobile phase. Pour the content on crushed ice. The dried product was azetidine-2-one $(4 \mathrm{a} / \mathrm{b} / \mathrm{c} / \mathrm{d}$ or $\mathrm{e})$ recrystallized with absolute alchohol.

The structures of these newly synthesized compounds of $(4 \mathrm{a} / \mathrm{b} / \mathrm{c} / \mathrm{d}$ and $\mathrm{e})$ were established by IR, ${ }^{1} \mathrm{H}$ NMR, ${ }^{13} \mathrm{C}$ NMR, Mass spectral data and microanalytical data.

\section{Experimental Section}

The IR, ${ }^{1} \mathrm{HNMR},{ }^{13} \mathrm{CNMR}$ and Mass spectral data of the synthesized compounds $4 \mathrm{a} / \mathrm{b} / \mathrm{c} / \mathrm{d}$ and $\mathrm{e}$ :

1) 3-chloro-1-(4-fluoro phenyl)-4-(pyridine-3-yl) azetidine-2-one (4a) MF: $\mathrm{C}_{14} \mathrm{H}_{10} \mathrm{ClFN}_{2} \mathrm{O}$. The product was synthesized according to general procedure 4.2 to afford the target compound as a white solid $0.52 \mathrm{~g}(68 \%)$.

IR (KBr $\left.4000-400 \mathrm{~cm}^{-1}\right)$ : 3052 (stretching of Ar-H), $2895(\mathrm{CH}), 1690(\mathrm{C}=\mathrm{O}$ of azetidinone), $1556(\mathrm{C}-\mathrm{N})$ and $720 \mathrm{~cm}^{-1}(\mathrm{C}-\mathrm{Cl})$.

${ }^{1} \mathrm{H}-\mathrm{NMR}$ (400 MHz, DMSO-d6): $\delta_{\mathrm{PPM}} 5.16(\mathrm{~d}, 1 \mathrm{H}, \mathrm{CH}), 5.44(\mathrm{~d}, 1 \mathrm{H}, \mathrm{CH})$, $7.25-7.29\left(\mathrm{~m}, 4 \mathrm{H}\right.$, of $\left.\mathrm{C}_{6} \mathrm{H}_{5} J=7.26\right), 7.38\left(\mathrm{q}, 1 \mathrm{H}, \mathrm{CH}\right.$ of $\left.\mathrm{C}_{6} \mathrm{H}_{4} \mathrm{~N} J=8.59\right), 7.86(\mathrm{~d}$, $1 \mathrm{H}, \mathrm{CH}$ of $\left.\mathrm{C}_{6} \mathrm{H}_{4} \mathrm{~N}\right), 8.45\left(\mathrm{~d}, 1 \mathrm{H}, \mathrm{CH}\right.$ of $\left.\mathrm{C}_{6} \mathrm{H}_{4} \mathrm{~N}\right)$ and $8.59\left(\mathrm{~s}, 1 \mathrm{H}, \mathrm{CH}\right.$ of $\left.\mathrm{C}_{6} \mathrm{H}_{4} \mathrm{~N}\right)$.

${ }^{13} \mathrm{C}-\mathrm{NMR}$ (75 MHz, DMSO-d6): $\delta_{\mathrm{PPM}} 162.9,162.2,148.4,146.9,140.8,135.5$, $133.1,123.4,123.2,123.2,115.7,115.7,68.1 \& 62.0$ corresponding to $C_{1}$ to $C_{14}$ respectively. MS 276.05 .

2) 3-chloro-1-(4-chloro phenyl)-4-(pyridine-3-yl) azetidine-2-one (4b) MF: $\mathrm{C}_{14} \mathrm{H}_{10} \mathrm{Cl}_{2} \mathrm{~N}_{2} \mathrm{O}$. The product was synthesized according to general procedure 4.2 to afford the target compound as a yellow precipitate $0.48 \mathrm{~g}(66 \%)$.

IR ( $\left.\mathrm{KBr} 4000-400 \mathrm{~cm}^{-1}\right): 3055$ (stretching of Ar-H), $2890(\mathrm{CH}), 1690(\mathrm{C}=$ O of azetidinone), $1550(\mathrm{C}-\mathrm{N})$ and $720 \mathrm{~cm}^{-1}(\mathrm{C}-\mathrm{Cl})$.

${ }^{1} \mathrm{H}-\mathrm{NMR}\left(400 \mathrm{MHz}\right.$, DMSO-d6): $\delta_{\mathrm{PPM}} 5.16(\mathrm{~d}, 1 \mathrm{H}, \mathrm{CH}), 5.44(\mathrm{~d}, 1 \mathrm{H}, \mathrm{CH})$, 7.34 - $7.54\left(\mathrm{~m}, 4 \mathrm{H}\right.$, of $\left.\mathrm{C}_{6} \mathrm{H}_{5} J=7.26\right), 7.38\left(\mathrm{q}, 1 \mathrm{H}, \mathrm{CH}\right.$ of $\left.\mathrm{C}_{6} \mathrm{H}_{4} \mathrm{~N} J=8.59\right), 7.86(\mathrm{~d}$, $1 \mathrm{H}, \mathrm{CH}$ of $\left.\mathrm{C}_{6} \mathrm{H}_{4} \mathrm{~N}\right), 8.45\left(\mathrm{~d}, 1 \mathrm{H}, \mathrm{CH}\right.$ of $\left.\mathrm{C}_{6} \mathrm{H}_{4} \mathrm{~N}\right)$ and $8.59\left(\mathrm{~s}, 1 \mathrm{H}, \mathrm{CH}\right.$ of $\left.\mathrm{C}_{6} \mathrm{H}_{4} \mathrm{~N}\right)$.

${ }^{13} \mathrm{C}-\mathrm{NMR}$ (75 MHz, DMSO-d6): $\delta_{\mathrm{PPM}} 162.2,148.4,146.9,140.8,137.6,133.5$, $133.3,129.0,129.0,125.6,125.6,123.4,68.1 \& 62.0$ corresponding to $C_{1}$ to $C_{14}$ respectively. MS 292.02.

3) 1-(4-bromo phenyl)-3-chloro-4-(pyridine-3-yl) azetidin-2-one (4c) MF: $\mathrm{C}_{14} \mathrm{H}_{10} \mathrm{BrClN}_{2} \mathrm{O}$. The product was synthesized according to general procedure 4.2 to afford the target compound as a yellow solid $0.55 \mathrm{~g}(64 \%)$. 
IR (KBr $4000-400 \mathrm{~cm}^{-1}$ ): 3052 (stretching of Ar-H), $2888(\mathrm{CH}), 1696(\mathrm{C}=$ O of azetidinone), $1555(\mathrm{C}-\mathrm{N})$ and $720 \mathrm{~cm}^{-1}(\mathrm{C}-\mathrm{Cl})$.

${ }^{1} \mathrm{H}-\mathrm{NMR}$ (400 MHz, DMSO-d6): $\delta_{\text {PPM }} 5.16$ (d, 1H, CH), 5.44 (d, 1H, CH), $7.38\left(\mathrm{q}, 1 \mathrm{H}, \mathrm{CH}\right.$ of $\left.\mathrm{C}_{6} \mathrm{H}_{4} \mathrm{~N} J=8.59\right), 7.86\left(\mathrm{~d}, 1 \mathrm{H}, \mathrm{CH}\right.$ of $\left.\mathrm{C}_{6} \mathrm{H}_{4} \mathrm{~N}\right), 8.13-8.20(\mathrm{~m}$, $4 \mathrm{H}$, of $\left.\mathrm{C}_{6} \mathrm{H}_{5} J=7.26\right), 8.45\left(\mathrm{~d}, 1 \mathrm{H}, \mathrm{CH}\right.$ of $\left.\mathrm{C}_{6} \mathrm{H}_{4} \mathrm{~N}\right)$ and $8.59\left(\mathrm{~s}, 1 \mathrm{H}, \mathrm{CH}\right.$ of $\left.\mathrm{C}_{6} \mathrm{H}_{4} \mathrm{~N}\right)$.

${ }^{13} \mathrm{C}-\mathrm{NMR}$ (75 MHz, DMSO-d6): $\delta_{\mathrm{PPM}} 162.2,148.4,146.9,140.8,138.5,136.7$, $136.7,133.5,131.8,131.8,123.4,122.3,68.1 \& 62.0$ corresponding to $C_{1}$ to $C_{14}$ respectively. MS 337.96.

4) 3-chloro-4-(pyridine-3-yl)-1-(4-(trifluoromethyl) phenyl) azetidine-2-one (4d) MF: $\mathrm{C}_{15} \mathrm{H}_{10} \mathrm{ClF}_{3} \mathrm{~N}_{2} \mathrm{O}$. The product was synthesized according to general procedure 4.2 to afford the target compound as a yellow precipitate $0.60 \mathrm{~g} \mathrm{(70 \% ).}$

IR ( $\mathrm{KBr} 4000-400 \mathrm{~cm}^{-1}$ ): 3058 (stretching of Ar-H), $2890(\mathrm{CH}), 1695(\mathrm{C}=$ O of azetidinone), $1561(\mathrm{C}-\mathrm{N})$ and $720 \mathrm{~cm}^{-1}(\mathrm{C}-\mathrm{Cl})$.

${ }^{1} \mathrm{H}-\mathrm{NMR}$ (400 MHz, DMSO-d6): $\delta_{\mathrm{PPM}} 5.16$ (d, 1H, CH), 5.44 (d, 1H, CH), $6.85-7.67\left(\mathrm{~m}, 4 \mathrm{H}\right.$, of $\left.\mathrm{C}_{6} \mathrm{H}_{5} J=7.26\right), 7.38\left(\mathrm{q}, 1 \mathrm{H}, \mathrm{CH}\right.$ of $\left.\mathrm{C}_{6} \mathrm{H}_{4} \mathrm{~N} J=8.59\right), 7.86(\mathrm{~d}$, $1 \mathrm{H}, \mathrm{CH}$ of $\left.\mathrm{C}_{6} \mathrm{H}_{4} \mathrm{~N}\right), 8.45\left(\mathrm{~d}, 1 \mathrm{H}, \mathrm{CH}\right.$ of $\left.\mathrm{C}_{6} \mathrm{H}_{4} \mathrm{~N}\right)$ and $8.59\left(\mathrm{~s}, 1 \mathrm{H}, \mathrm{CH}\right.$ of $\left.\mathrm{C}_{6} \mathrm{H}_{4} \mathrm{~N}\right)$.

${ }^{13} \mathrm{C}-\mathrm{NMR}$ (75 MHz, DMSO-d6): $\delta_{\mathrm{PPM}} 162.2,148.4,146.9,142.8,140.8,133.8$, $133.8,133.5,132.1,125.3,125.3,124.1,123.4,68.1 \& 62.0$ corresponding to $C_{1}$ to $\mathrm{C}_{15}$ respectively. MS 326.04.

5) 3-chloro-1-(4-methoxy phenyl)-4-(pyridine-3-yl) azetidine-2-one (4e) MF: $\mathrm{C}_{15} \mathrm{H}_{13} \mathrm{ClN}_{2} \mathrm{O}_{2}$. The product was synthesized according to general procedure 4.2 to afford the target compound as a yellow precipitate $0.66 \mathrm{~g}(74 \%)$.

IR (KBr $4000-400 \mathrm{~cm}^{-1}$ ): 3065 (stretching of Ar-H), $2980(\mathrm{CH}), 1692(\mathrm{C}=$ O of azetidinone), $1560(\mathrm{C}-\mathrm{N})$ and $720 \mathrm{~cm}^{-1}(\mathrm{C}-\mathrm{Cl})$.

${ }^{1} \mathrm{H}-\mathrm{NMR}$ (400 MHz, DMSO-d6): $\delta_{\mathrm{PPM}} 3.83$ (s, 3H, $\mathrm{CH}_{3}$ ), 5.16 (d, 1H, CH), $5.44(\mathrm{~d}, 1 \mathrm{H}, \mathrm{CH}), 7.04-7.38\left(\mathrm{~m}, 4 \mathrm{H}\right.$, of $\left.\mathrm{C}_{6} \mathrm{H}_{5} J=7.26\right), 7.38\left(\mathrm{q}, 1 \mathrm{H}, \mathrm{CH}\right.$ of $\mathrm{C}_{6} \mathrm{H}_{4} \mathrm{~N}$ $J=8.59), 7.86\left(\mathrm{~d}, 1 \mathrm{H}, \mathrm{CH}\right.$ of $\left.\mathrm{C}_{6} \mathrm{H}_{4} \mathrm{~N}\right), 8.45\left(\mathrm{~d}, 1 \mathrm{H}, \mathrm{CH}\right.$ of $\left.\mathrm{C}_{6} \mathrm{H}_{4} \mathrm{~N}\right)$ and $8.59(\mathrm{~s}, 1 \mathrm{H}$, $\mathrm{CH}$ of $\left.\mathrm{C}_{6} \mathrm{H}_{4} \mathrm{~N}\right)$.

${ }^{13} \mathrm{C}-\mathrm{NMR}$ (75 MHz, DMSO-d6): $\delta_{\mathrm{PPM}} 162.2,158.9,148.4,146.9,140.8,133.5$, $131.8,123.4,119.0,119.0,114.5,114.5,68.1,62.0 \& 55.8$ corresponding to $C_{1}$ to $\mathrm{C}_{15}$ respectively. MS 288.07.

6) The microanalytical data and m.pts. Data are listed in Table 2, for the synthesized compounds $(4 \mathrm{a} / \mathrm{b} / \mathrm{c} / \mathrm{d}$ and $\mathrm{e})$.

Table 2. Microanalytical data and M.P. data for the synthesized compounds $4 \mathrm{a} / \mathrm{b} / \mathrm{c} / \mathrm{d} \& \mathrm{e}$.

\begin{tabular}{|c|c|c|c|c|c|c|c|}
\hline \multirow{2}{*}{$\begin{array}{c}\text { Comp } \\
\text { No }\end{array}$} & \multirow{2}{*}{$\mathrm{R}$} & \multirow{2}{*}{ MW } & \multirow{2}{*}{$\mathrm{Mp}\left({ }^{\circ} \mathrm{C}\right)$} & \multirow{2}{*}{$\begin{array}{c}\text { Yield } \\
(\%)\end{array}$} & \multicolumn{3}{|c|}{ Found (Calc) (\%) } \\
\hline & & & & & $\mathrm{C}$ & $\mathrm{H}$ & $\mathrm{N}$ \\
\hline $4 a$ & $\mathrm{~F}$ & 276.69 & $154-156$ & 68 & $60.70(60.77)$ & $3.59(3.64)$ & $10.05(10.12)$ \\
\hline $4 \mathrm{~b}$ & $\mathrm{Cl}$ & 293.02 & $150-152$ & 66 & $57.29(57.36)$ & $3.39(3.44)$ & $9.49(9.56)$ \\
\hline $4 c$ & $\mathrm{Br}$ & 335.97 & $160-163$ & 64 & $49.74(49.81)$ & $2.94(2.99)$ & $8.23(8.30)$ \\
\hline $4 \mathrm{~d}$ & $\mathrm{CF}_{3}$ & 326.70 & $168-170$ & 70 & $55.08(55.15)$ & $3.04(3.09)$ & $8.50(8.57)$ \\
\hline $4 e$ & $\mathrm{OCH}_{3}$ & 288.73 & $162-164$ & 74 & $62.33(62.40)$ & $4.49(4.54)$ & $9.63(9.70)$ \\
\hline
\end{tabular}




\section{Conclusion}

In conclusion, we have demonstrated the synthesis of a series of novel pyridine containing substituted phenyl azetidine-2-one derivatives of (4a-e) involving condensation of nicotinaldehyde and 4-substituted anilines via Schiff base intermediates. Some of these compounds may serve as good pharmacological activities.

\section{Acknowledgements}

The author V. Esther Rani thanks to UGC-Post Doctoral Fellowship, New Delhi for financial assistance. They are also thankful to IICT Hyderabad and CDRI Lucknow for spectral and analytical data.

\section{References}

[1] Brodowska, K. and Lodyga-Chruścińska, E. (2014) Schiff Bases Interesting Range of Applications in Various Fields of Science. Chemik, 68, 129-134.

[2] Kundariyal, D.S., Patel, P.K. and Bheshdadia, B.M. (2014) Synthesis, Characterization and Biological Activity of 4-Thiazolidinone Derivatives Containing 1H-Pyrazolo[3,4-b] Pyridine Nucleus. Der Chemica Sinica, 5, 138-143.

http://pelagiaresearchlibrary.com/der-chemica-sinica/vol5-iss1/DCS-2014-5-1-138143.pdf

[3] Kumar, P.P. and Rani, B.L. (2011) Synthesis and Characterization of New Schiff Bases Containing Pyridine Moiety and Their Derivatives as Antioxidant Agents. International Journal of Chem Tech Research, 3, 155-160.

[4] Bhatia, M.S., Mulani, A.K., Chaudhary, P.B., Ingale, K.B. and Bhatia, N.M. (2009) Synthesis and QSAR Analysis of 5-Substituted (Aryl Methylene) Pyridine-2-Amine Derivatives as Potential Antibacterials. International Journal of Drug Discovery, 1, 1-9. https://doi.org/10.9735/0975-4423.1.1.1-9

[5] Amr, A.G., Mohamed, A.M., Mohamed, S.F., Abdel-Hafez, N.A., El-Fotooh, G. and Hammam, A. (2006) Anticancer Activities of Some Newly Synthesized Pyridine, Pyrane and Pyrimidine Derivatives. Bioorganic \& Medicinal Chemistry, 14, 5481-5488. http://www.sciencedirect.com/science/article/pii/S0968089606003452 https://doi.org/10.1016/j.bmc.2006.04.045

[6] Jansen, B.A.J., van der Zwan, J., den Dulk, H., Brouwer, J. and Reedijk, J. (2001) Dinuclear Alkyl Diamine Platinum Antitumor Compounds: A Structure-Activity Relationship Study. Journal of Medicinal Chemistry, 44, 245-249.

http://pubs.acs.org/doi/pdf/10.1021/jm0010163 https://doi.org/10.1021/jm0010163

[7] Hisashi, S., Takao, I., Tetsuya, I., Yuki, K., Hideki, Y. and Itsuo, U. (2000) 4-Aminoquinolines: Novel Nociceptin Antagonists with Analgesic Activity. Journal of Medicinal Chemistry, 43, 4667-4677. https://doi.org/10.1021/jm0002073

[8] Věra, K., Martin, S., Waisser, W.K., Milan, P. and Jarmila, K. (1999) New Pyridine Derivatives as Potential Antimicrobial Agents. Il Farmaco, 54, 666-672. https://doi.org/10.1016/S0014-827X(99)00078-6

[9] Padmakant and Saksena R.K. (2003) Introduction and Literature Review of Quinazolines, Azetidine-2-Ones, Thiazolidin-4-One, Tetrazoles, 1, 2, 4 Triazoles, 1, 3, 4 Oxa Diazolesand Its Derivatives. Indian Journal of Heterocyclic Chemistry, 12, 315.

[10] Patel, K.D., Mistry, B.D. and Desai, K.R. (2004) A Brief Review on Five Membered 
Heterocyclic Compounds as Pesticides. Journal of Indian Chemical Society, 81, 784.

[11] Pawar, R.B. and Mulwad, V.V. (2004) Synthesis of Some Biologically Active Pyrazole, Thiazolidinone, and Azetidinone Derivatives. Chemistry of Heterocyclic Compounds, 40, 219-226. https://doi.org/10.1023/B:COHC.0000027896.38910.d1

[12] Rajasekaran, A. and Murugesan, S. (2005) Synthesis and Characterization of Some Novel Azetidinone Derivatives as Anti-Bacterial and Anti-Convulsant Agents. Journal of Pharmacy \& Bioresources, 2, 162-168.

[13] Vasoya, S.L., Patel, M.R., Dobaria, S.V. and Joshi, S.H. (2005) Facile Synthesis of Some New Azetidinones and Acetyl Oxadiazoles Bearing Benzo[b]Thiophene Nucleus as a Potent Biological Active Agent. Indian Journal of Chemistry-B, 44B, 405-409.

[14] Naik, B. and Desai, K.R. (2006) Novel Approach for the Rapid and Efficient Synthesis of Heterocyclic Schiff Bases and Azetidinones under Microwave Irradiation. Indian Journal of Chemistry, 45B, 267.

[15] Desai, K.G. and Desai, K.R. (2006) Green Route for the Heterocyclization of 2-Mercaptobenzimidazole into $\beta$-Lactum Segment Derivatives Containing -CONH- Bridge with Benzimidazole: Screening in Vitro Antimicrobial Activity with Various Microorganisms. Bioorganic \& Medicinal Chemistry, 14, 8271-8279. https://doi.org/10.1016/j.bmc.2006.09.017

[16] Parekh, J., Inamdhar, P., Nair, R., Baluja, S. and Chanda, S. (2005) Synthesis and Antibacterial Activity of Some Schiff Bases Derived from 4-Aminobenzoic Acid. Journal of the Serbian Chemical Society, 70, 1155-1158. https://doi.org/10.2298/JSC0510155P

[17] Wadhwa, D., Arora, V., Hussain, K. and PragiArora (2014) $\alpha$-Tosyloxyacetophenones: As a Precursor in Ultrasonic Assisted Multicomponent, Diastereoselective Synthesis of Trans-2,3-Dihydrofuro[3,2-c] Coumarins Using [BMIm] OH and Their Antimicrobial Evaluation. Journal of Chemical and Pharmaceutical Research, 6, 655-661.

[18] Magaldi, S., Mata-Esayag, S., Capriles, C.H.D., Perez, C., Colellac, M., Olaizola and Ontiveros, Y. (2004) Well Diffusion for Antifungal Susceptibility Testing. International Journal of Infectious Diseases, 8, 39-45. https://doi.org/10.1016/j.ijid.2003.03.002 